\title{
Kajian Dampak dan Adaptasi Perubahan Iklim di Kalimantan Tengah
}

\author{
Sari Marlina ${ }^{1 *}$, Kamaliah $^{2}$ \\ 1,2Program Studi Teknik Lingkungan, Fakultas Teknik dan Informatika, Universitas Muhammadiyah Palangkaraya \\ *surel: sarimarlina712@gmail.com
}

\begin{abstract}
Climate change is affecting several regions of Indonesia which are geographically highly vulnerable, so that adaptation is needed as an effort to increase community resilience for sustainable development. Central Kalimantan is one of the provinces that is vulnerable to the impacts of climate change that is currently happening. Based on this phenomenon, this study aims to see the impacts and forms of climate change in Central Kalimantan through descriptive qualitative research. The research was conducted from May to November 2019 with data research techniques in the form of observation and literature study. The results showed that, although climate change in Central Kalimantan was not extreme, it had an impact on people suffering from Dengue Fever and malaria. Diseases related to environmental conditions and people's behavior due to climate change. Climate change adaptation should be carried out as a process of changing climate change from actual or future conditions in order to better prepare to withstand physical phenomenon, such as green open spaces, climatefriendly management and agricultural systems.
\end{abstract}

Keywords:

Impact,

Adaptation,

Climate change

Submitted: March 2020

Reviewed: January 2021

Published: February 2021

\section{INTISARI}

Perubahan iklim melanda beberapa wilayah Indonesia yang secara geografis mempunyai tingkat kerentanan cukup tinggi, sehingga diperlukan adaptasi sebagai upaya meningkatkan ketahanan masyarakat untuk pembangunan berkelanjutan. Kalimantan Tengah termasuk rentan terhadap dampak dari perubahan iklim yang saat ini terjadi. Berdasarkan fenomena tersebut, penelitian ini bertujuan mengetahui dampak dan bentuk adaptasi perubahan iklim di Kalimatan Tengah melalui penelitian kualitatif deskriptif. Penelitian dilakukan pada Mei sampai November 2019 dengan teknik pengumpulan data berupa observasi dan kajian studi litelatur. Hasil penelitian menunjukkan bahwa, adanya perubahan iklim di Kalimantan Tengah meskipun tidak bersifat ekstrim namun berdampak pada masyarakat menderita penyakit Demam Berdarah Dengue dan malaria. Penyakit ini berkaitan dengan kondisi lingkungan dan perilaku masyarakat karena perubahan iklim. Adaptasi perubahan iklim yang sebaiknya dilakukan sebagai proses penyesuaian terhadap perubahan iklim dari kondisi iklim aktual atau di masa depan agar dapat mempersiapkan dengan lebih baik untuk bertahan dari peristiwa fisik, seperti ketersediaan ruang terbuka hijau, pengelolaan dan system pertanian yang ramah iklim.
Kata Kunci:

Dampak, adaptasi, perubahan iklim

Diterima: Maret 2020

Direview: Januari 2021

Dipublikasi: Februari 2021 


\section{PENDAHULUAN}

Perubahan iklim yang teriadi saat ini sudah mulai dirasakan, banyak kejadian iklim melanda beberapa bagian wilayah Indonesia yang secara geografis mempunyai tingkat kerentanan yang cukup tinggi, sehingga diperlukan tindakan nyata adaptasi untuk meningkatkan ketahanan masyarakat sebagai sebuah komponen penting yang diperlukan dalam pembangunan berkelanjutan yang tahan terhadap goncangan/gangguan iklim. Banyaknya kegiatan perekonomian dilakukan di wilayah pesisir dan masyarakat yang mengandalkan hidupnya pada sektor yang mempunyai tingkat kepekaan tinggi terhadap iklim, seperti pertanian. Kondisi geografis ini menjadikan Indonesia sangat rentan terhadap perubahan iklim.

Intergovernmental Panel on Climate Change [1] mendefinisikan perubahan iklim sebagai perubahan yang terjadi terhadap iklim dari waktu ke waktu, baik itu karena faktor alam maupun dampak dari aktivitas manusia. Dampak perubahan iklim yang terjadi saat ini sudah mulai dirasakan, melanda dibeberapa daerah di Indonesia akibat kenaikan gas rumah kaca yang menyebabkan perubahan iklim. Pemerintah Kalimantan Tengah menetapkan penyusunan Rencana Aksi Daerah Penurunan Emisi Gas Rumah Kaca Kalimantan Tengah melalui Peraturan Gubernur Kalimantan Tengah No. 36 Tahun 2012 [2]. Perubahan iklim tidak dapat kita hentikan namun harus kita hadapi dengan mengurangi laju perubahan iklim dan beradaptasi, diperlukan tindakan yang nyata guna keberlanjutan terhadap gangguan iklim.

Adaptasi perubahan iklim adalah proses penyesuaian dan respon terhadap dampak perubahan iklim dari kondisi iklim aktual atau di masa depan. Di dalam sistem manusia, adaptasi bertujuan untuk menghindari bahaya yang bersifat moderat dan/atau termasuk memanfaatkan peluang yang ada. Di dalam sistem alam, adaptasi yang berbentuk intervensi dari manusia dapat memfasilitasi penyesuaian terhadap kondisi iklim yang diharapkan dan dampaknya [1].

Shocks/fast onset/bencana merupakan dampak perubahan iklim yang terjadi secara cepat contohnya bajir, gelombang panas, angin topan, dan cuaca ekstrim lainnya. Stress/slow onset/tekanan merupakan dampak perubahan iklim yang terjadi secara perlahanlahan contohnya kenaikan muka air laut, perubahan waktu periode musim. Kalimantan Tengah sebagai salah provinsi yang rentan terhadap bencana hidrometeorologis seperti banjir saat musim penghujan dan kekeringan pada musim kemarau, Sementara itu, kemampuan dari sistem sosial dan ekologi untuk menyerap gangguan, kemampuan untuk mengorganisasikan secara mandiri, dan kemampuan untuk beradaptasi terhadap tekanan dan perubahan masih sangat perlu di ketahui agar strategi dalam bentuk adaptasi terhadap dampak perubahan iklim dapat membuat masyarakat dapat bertahap hidup dan bertahan di saat terjadi krisis Iklim . 


\section{METODOLOGI}

Penelitian ini merupakan penelitian deskriptif kualitatif dengan metode studi kasus. Teknik pengumpulan data dengan cara observasi adalah mencatat semua informasi yang ada di lapangan terhadap situasi atau peristiwa yang ada. Serta studi literatur dan dokumentasi. Lokasi penelitian di Palangka Raya dengan waktu penelitian pada bulan Mei sampai November 2019.

\section{HASIL DAN PEMBAHASAN}

\section{Kondisi Daerah}

Provinsi Kalimantan Tengah, dengan ibukota Palangka Raya, terletak antara $0^{\circ} 45^{\prime}$ Lintang Utara s.d. $3^{\circ} 30^{\prime}$ Lintang Selatan dan $111^{\circ}$ s.d. $116^{\circ}$ Bujur Timur. Provinsi Kalimantan Tengah merupakan provinsi terluas kedua di Indonesia setelah Provinsi Papua dengan luas wilayah mencapai $153.564 \mathrm{Km}^{2}$, memiliki 11 (sebelas) sungai besar dan tidak kurang dari 33 (tiga puluh tiga) sungai kecil/anak sungai, keberadaannya menjadi salah satu ciri khas Provinsi Kalimantan Tengah. Adapun Sungai Barito dengan panjang mencapai $900 \mathrm{~km}$ memiliki kedalaman mencapai 8 meter, merupakan sungai terpanjang di Kalimantan Tengah sehingga dapat dilayari hingga $700 \mathrm{~km}$.

Batas Provinsi Kalimantan Tengah di bagian utara yaitu sabuk pegunungan Muller Schwanner, paling tidak 52 bukit, dari ketinggian 343 meter yaitu Bukit Ancah sampai 2278 meter yaitu Bukit Raya. Bukit Batu Tatau dengan ketinggian 1652 meter paling ujung perbatasan Kalimantan TengahKalimantan Timur. Titik tertinggi wilayah Kalimantan Tengah terdapat di Gunung Batu Sambang dengan ketinggian hingga 1660 Meter di atas permukaan laut (dpl).

Sebagai daerah yang beriklim tropis, wilayah Provinsi Kalimantan Tengah rata-rata mendapat sinaran matahari sekitar 56,18\% per tahun, dimana kondisi udara relatif cukup panas yaitu pada siang hari mencapai $33^{\circ} \mathrm{C}$ dan malam hari $23^{\circ} \mathrm{C}$. Sementara rata-rata intensitas curah hujan per tahun relatif tinggi yaitu mencapai $331,68 \mathrm{~mm}$.

Berdasarkan Undang-Undang Republik Indonesia Nomor 5 Tahun 2002 tentang Pembentukan Kabupaten Katingan, Kabupaten Seruyan, Kabupaten Sukamara, Kabupaten Lamandau, Kabupaten Gunung Mas, Kabupaten Pulang Pisau, Kabupaten Murung Raya, Dan Kabupaten Barito Timur Di Provinsi Kalimantan Tengah, Provinsi Kalimantan Tengah terdiri atas 13 Kabupaten dan 1 Kota, yaitu: Kota Palangka Raya ibukota Palangka Raya, Kabupaten Kotawaringin Barat ibukota Pangkalan Bun, Kabupaten Kotawaringin Timur ibukota Sampit, Kabupaten Kapuas ibukota Kuala Kapuas, Kabupaten Barito Selatan ibukota Buntok, Kabupaten Barito Utara ibukota Muara Teweh, Kabupaten Lamandau ibukota Nanga Bulik, Kabupaten Sukamara ibukota Sukamara, Kabupaten Seruyan ibukota Kuala Pembuang, Kabupaten Katingan ibukota Kasongan, Kabupaten Gunung Mas ibukota Kuala Kurun, Kabupaten Pulang Pisau ibukota Pulang Pisau, Kabupaten Barito Timur ibukota Tamiang Layang, Kabupaten Murung Raya ibukota Puruk Cahu. Serta terdiri dari 136 Kecamatan, 138 Kelurahan dan 1574 Desa. Adapun jumlah penduduk tahun 2015 yaitu 2.495 .035 jiwa [3].

\section{Topografi dan Fisiografi}

Kondisi fisik wilayah Provinsi Kalimantan Tengah, terdiri atas daerah pantai dan rawa yang terdapat di wilayah Bagian Selatan sepanjang \pm $750 \mathrm{~km}$ pantai Laut Jawa, yang membentang dari Timur ke Barat dengan ketinggian antara 0-50 m dpl dan tingkat kemiringan $0 \%-8 \%$. 
Tabel 1. Penyebaran dan Luas masing-masing Kelas Ketinggian Wilayah Daratan Provinsi Kalimantan Tengah

\begin{tabular}{cccc}
\hline No & $\begin{array}{c}\text { Kelas Ketinggian } \\
(\mathrm{m} \mathrm{dpl})\end{array}$ & Luas (Ha) & Persentase \\
\hline 1. & $0-7$ & 2.105 .510 & 13,69 \\
2. & $7-25$ & 2.269 .717 & 14,76 \\
3. & $25-100$ & 6.398 .923 & 41,66 \\
4. & $100-500$ & 3.327 .459 & 21,63 \\
5. & $>500$ & 1.278 .391 & 8,31 \\
\hline
\end{tabular}

Sumber. Data : Dishut Propinsi Kalteng, 2019 [3]

Sementara itu wilayah daratan dan perbukitan berada bagian tengah, sedangkan pegunungan berada di bagian Utara dan Barat Daya dengan ketinggian 50 - $100 \mathrm{dpl}$ dan tingkat kemiringan rata-rata sebesar $25 \%$.

Tabel 2. Luas masing-masing Kelas Kemiringan Wilayah Daratan Provinsi Kalimantan Tengah

\begin{tabular}{cccc}
\hline No & \multicolumn{1}{c}{ Kelas Lereng $(\%)$} & Luas $(\mathrm{Ha})$ & Persentase \\
\hline 1. & $0-8$ (Datar) & $6,940,144.05$ & 46.12 \\
2. $8-15$ (Landai) & $1,552,839.80$ & 10.32 \\
3. $15-25$ (Agak Curam) & $3,977,865.28$ & 26.44 \\
4. $25-40$ (Curam) & $1,694,814.85$ & 11.26 \\
5. $>40$ (Sangat Curam) & $881,357.24$ & 5.86 \\
\hline
\end{tabular}

Sumber. Data : Dishut Propinsi Kalteng, 2019 [3]

Provinsi Kalimantan Tengah terdiri atas 6 wilayah fisiografi, tetapi didominasi oleh daratan dan perbukitan pedalaman.

Tabel 3. Wilayah Fisiografi di Provinsi Kalimantan Tengah

\begin{tabular}{lc}
\hline No & Wuas $\left(\mathrm{Km}^{2}\right)$ \\
\hline 1. Daratan rendah pesisir & 36.870 \\
2. Undak-undak pedalaman & 37.310 \\
3. Daratan dan perbukitan & 57.124 \\
pedalaman & \\
4. Pegunungan Schwaner & 9.000 \\
5. Pegunungan Muller & 11.000 \\
6. Pegunungan Meratus & 2.300 \\
\hline
\end{tabular}

Sumber. Data : Dishut Propinsi Kalteng, 2019 [3]

\section{Geologi}

Berdasarkan kerangka tektonik regional Kalimantan, daerah Provinsi Kalimantan Tengah termasuk dalam cekungan Barito yang terletak disisi tenggara lempeng mikro Sunda. Bagian Utara dipisahkan dengan cekungan Kutai oleh "Paternoster Fault System" dan "Barito - Kutai Crose Heigh". Sebelah Timur dipisahkan dengan cekungan asem-asem dan cekungan pasir oleh pegunungan Meratus. Disebelah Selatan merupakan batas tidak tegas dengan cekungan Jawa Timur dan disebelah Barat oleh tinggian Sunda.

\section{Jenis Tanah}

Sebagian besar wilayah daratan Kalimantan Tengah terdiri dari jenis tanah podsolik merah kuning. Pada dasarnya jenis tanah di Kalimantan Tengah terdiri dari organosol, laterit, regosol, alluvial, podsol, lithosol dan latosal.

Tabel 4. Luas masing-masing Jenis Tanah di Wilayah Daratan Provinsi Kalimantan Tengah

\begin{tabular}{|c|c|c|c|}
\hline No & Jenis Tanah & Luas $(\mathrm{Ha})$ & Persentase \\
\hline 1. & Podsolik Merah Kuning & 6.033 .693 & 39,60 \\
\hline 2. & Organosol & 2.534 .766 & 11,63 \\
\hline 3. & Laterit & 2.118 .460 & 13,90 \\
\hline 4. & Regosol & 1.452 .305 & 9,53 \\
\hline 5. & Alluvial & 1.423 .803 & 9,34 \\
\hline 6. & Podsol & 1.040 .452 & 6,51 \\
\hline 7. & Lithosol & 413.793 & 2,71 \\
\hline 8. & Latosol & 269.360 & 1,77 \\
\hline
\end{tabular}

Sumber. Data : Dishut Propinsi Kalteng, 2019 [3]

Berdasarkan klasifikasi iklim Schmid dan Ferguson, wilayah Provinsi Kalimantan Tengah termasuk tipe iklim $A$, hal ini ditandai dengan adanya jumlah bulan basah lebih banyak dari bulan kering dan pola penyebaran curah hujan hampir merata pada semua wilayah. Dari Data Iklim yang diperoleh dari Badan Meteorologi dan Geofisika Kota Palangkaraya diperoleh data iklim selama kurun waktu 18 tahun (Desember 2001 sampai dengan Desember 2019) dan setelah di buat dalam bentuk grafik sebagai berikut: 
a. Suhu/ Temperatur

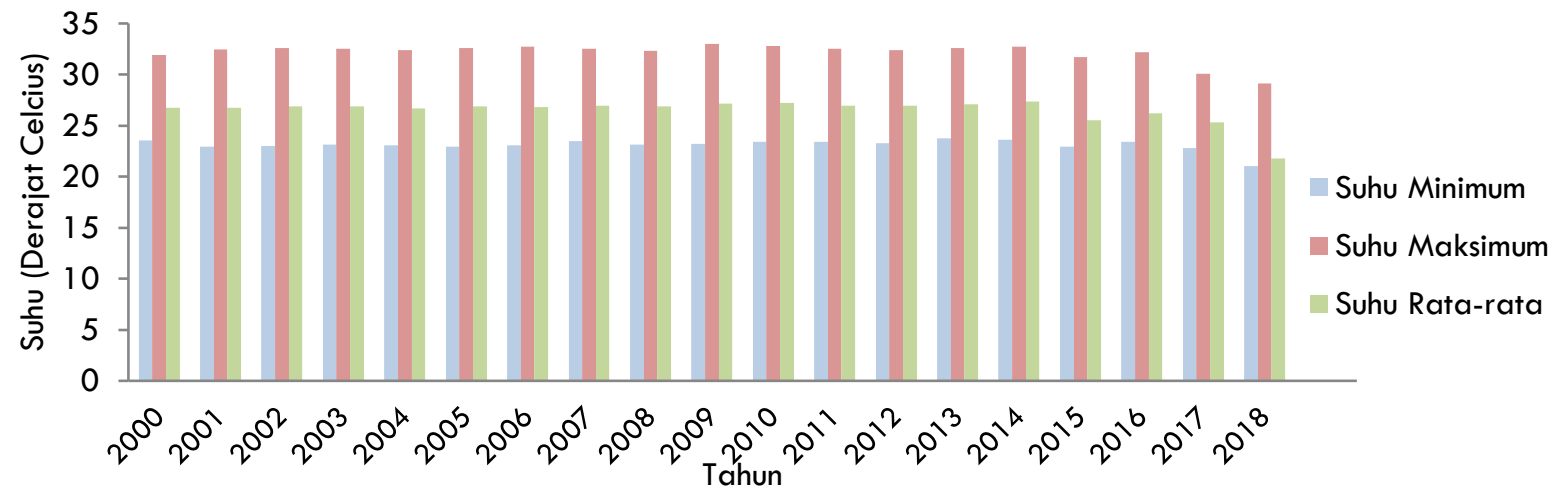

Gambar 1. Suhu Kota Palangka Raya (Sumber Data. BMKG.Laporan Iklim Per Propinsi, 2018) [4]

Berdasarkan grafik di atas bahwa untuk suhu minimum di kota Palangkaraya tidak terlalu berpengaruh ekstrim dengan range suhu yang pergerakannya berkisar rata-rata antara 17-26 celcius $^{\circ}$ untuk suhu maksimumnya ada terjadi perubahan yang cukup ekstrim yaitu pada tahun 2011 terjadi penurunan suhu atau temperatur dan tahun selanjutnya kembali normal, dan untuk suhu rata-rata tidak terjadi perubahan yang ekstrim, suhu berkisar antara $25-30 \mathrm{C}^{\circ}$.

b. Curah Hujan

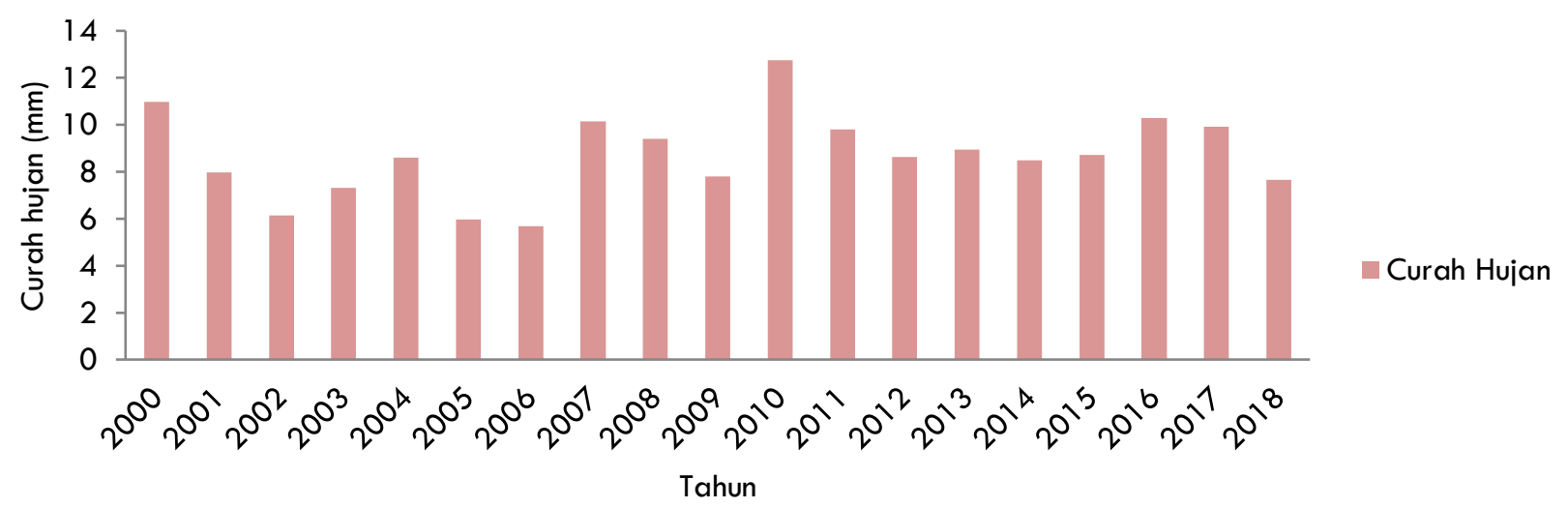

Gambar 2. Curah hujan Kota Palangka Raya (Sumber Data. BMKG.Laporan Iklim Per Propinsi, 2018) [4]

Curah hujan di palangkaraya tidak ada perubahan ekstrim, hal ini normal karena curah hujan tinggi pada bulan-bulan akhir tahun yang dimana pada bulan-bulan tersebut adalah musim hujan, meskipun agak tinggi pada tahun 2016.

\section{c. Kelembaban Rata-rata}

Kelembaban rata-rata kota Palangkaraya tidak terlalu ekstrim perubahannya berkisar ratarata $60-90 \%$

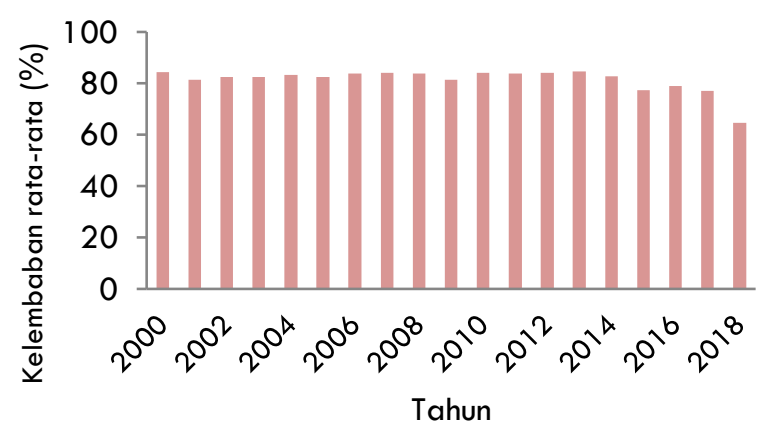

Gambar 3. Kelembaban Rata-rata (Sumber Data. BMKG.Laporan Iklim Per Propinsi, 2018) [4] 
d. Lama Penyinaran Sinar Matahari

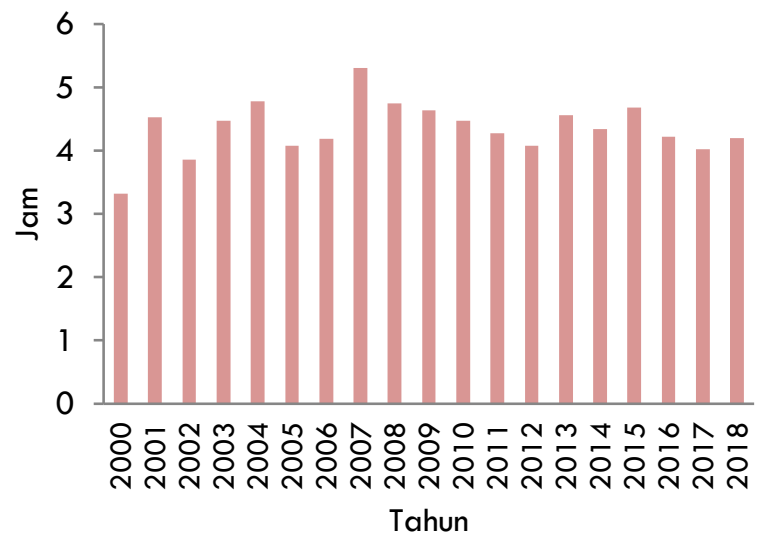

Gambar 4. Lama penyinaran sinar matahari (Sumber Data. BMKG.Laporan Iklim Per Propinsi, 2018) [4]
Berdasarkan grafik di atas bisa dilihat bahwa lama penyinaran di palangkaraya tidak ada perubahan ekstrim, meskipun agak tinggi pada tahun 2015-2016 di mana lama penyinaran hampir menyentuh 10 jam.

e. Kecepatan Angin

Kecepatan angin rata-rata di Palangka Raya ada perubahan ekstrim, karena pada tahun 2006 , 2009, dan 201 2, kecepatan angin rata-rata sampai 9 knot dan kecepatan angin terbesar pada tahun 2012 dan 2013, kecepatan angin terbesar sampai 45 knot.

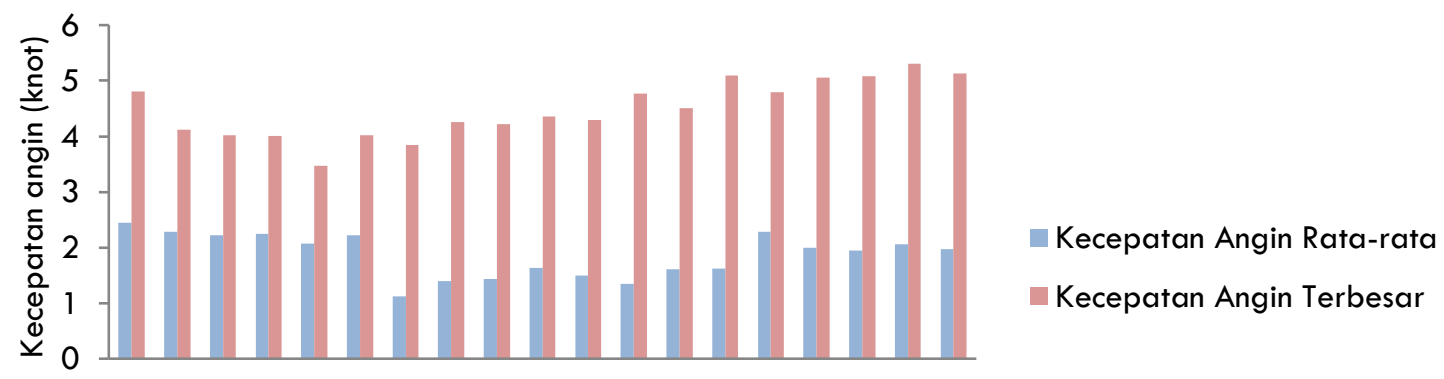

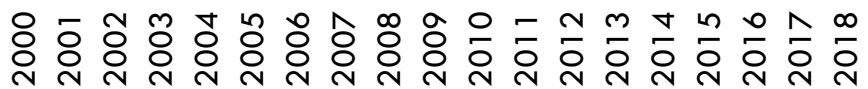

Tahun

Gambar 5. Kecepatan Angin (Sumber Data. BMKG.Laporan Iklim Per Propinsi, 2018) [4]

Virulensi Penyakit Demam Berdarah (DBD) dan Malaria

1. Penyakit Demam Berdarah (DBD)

Demam Berdarah Dengue adalah penyakit yang disebabkan oleh virus Dengue dan ditularkan oleh vektor nyamuk Aedes Aepyty. Penyakit DBD cenderung meningkat dan menyebar luas dan seringkali disertai kejadian luar biasa (KLB), sehingga menimbulkan keresahan di masyarakat karena menyebar dengan cepat dan dapat menyebabkan kematian. Penyakit DBD dapat muncul sepanjang tahun dan dapat menyerang seluruh kelompok umur. Penyakit ini berkaitan dengan kondisi lingkungan dan perilaku masyarakat.
Adanya perubahan iklim di Kalimantan Tengah tersebut berdampak pada penyakit Demam Berdarah Dengue. Pada tahun di 2017 di Provinsi Kalimantan Tengah dilaporkan terdapat 894 kasus DBD, lebih sedikit bila dibandingkan dengan jumlah kasus DBD pada tahun 2016 sebanyak 1762 kasus DBD, dengan jumlah kematian sebanyak 18 orang lebih sedikit dibandingkan jumlah kematian pada tahun 2016 yang berjumlah 24 orang.

Insidens Rate/Angka Kesakitan sebesar 34,3 per 100.000 penduduk dan CFR/angka kematian sebesar 2\%. Target Renstra Kementerian Kesehatan untuk angka kesakitan DBD tahun 2017 sebesar < 49 per 100.000 penduduk, dengan 
demikian Provinsi Kalimantan Tengah telah mencapai target yang telah ditetapkan Kementerian Kesehatan. Berikut ini gambaran Incidence Rate (IR) masing-masing Kabupaten/Kota di Provinsi Kalimantan Tengah tahun 2017.

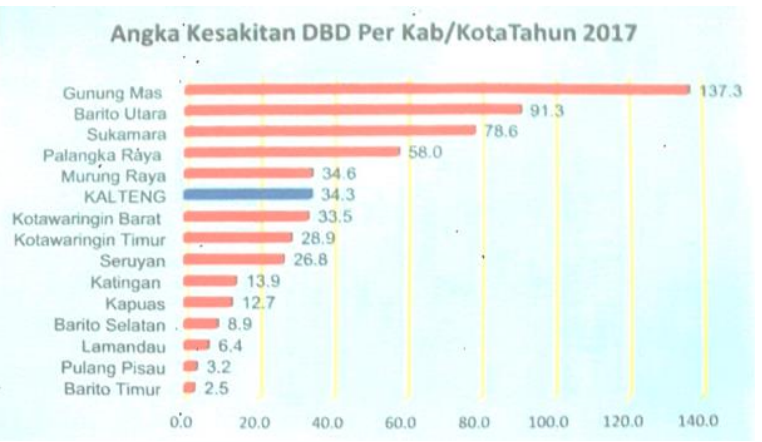

Gambar 6.Incidence Rate Kasus DBD di Provinsi Kalimantan Tengah Tahun 2017 (Sumber data. Profil Kabupanen/Kota dan Bidang P2P, Tahun 2017)

\section{Penyakit Malaria}

Pada Sustainable Development Goals (SDGs) dengan tujuan globalnya menjamin kehidupan yang sehat dan meningkatkan kesejahteraan seluruh penduduk semua usia, dengan target meningkatkan eliminasi malaria di setiap kabupaten kota maupun provinsi. Hingga saat ini Malaria masih menjadi permasalahan kesehatan masyarakat karena mempengaruhi angka kesakitan dan kematian pada bayi dan ibu hamil serta dapat menurunkan produktifitas kerja dan biaya untuk pengobatan.

Malaria disebabkan parasit Plasmodium yang hidup dan berkembang biak dalam sel darah merah manusia yang ditularkan oleh nyamuk malaria (Anopheles) betina. Menyerang semua golongan umur (bayi hingga dewasa) dan semua jenis kelamin [5].

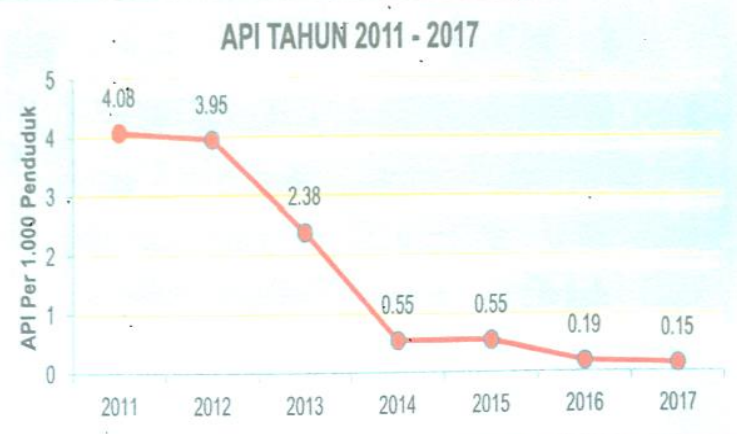

Gambar 7. Angka Kesakitan Malaria (annual Paracite Incidence/API) Per 1.000 Penduduk Beresiko di Provinsi Kalimantan Tengah Tahun 2011-2017) (Sumber data : Profil Kabupaten Kota dan Bidang P2P, Tahun 2018)

Malaria masih menjadi permasalahan kesehatan masyarakat karena mempengaruhi angka kesakitan dan kematian pada bayi dan ibu hamil serta dapat menurunkan produktifitas kerja dan biaya untuk pengobatan. Malaria disebabkan parasit Plasmodium yang hidup dan berkembang biak dalam sel darah merah manusia yang ditularkan oleh nyamuk malaria (Anopheles) betina. Menyerang semua golongan umur (bayi hingga dewasa) dan semua jenis kelamin [5].

\section{Adaptasi Perubahan Iklim di Kalimantan Tengah} Rencana Tata Ruang Wilayah (RTRW) dan Rencana Detail Tata Ruang (RDTR) tidak mempunyai peranan dalam mengurangi dampak perubahan iklim, atau dengan kata lain RTRW dan RDTR tidak diperuntukkan untuk adaptasi perubahan iklimn namun rencana tata ruang memiliki potensi untuk adaptasi terhadap perubahan iklim. Menurut Stern [6], perencanaan tata ruang dapat menfasilitasi adaptasi terhadap perubahan iklim dan menekankan bahwa adaptasi harus diintergrasikan ke dalam tiap tingkat perencanaan baik tingkat daerah maupun tingkat nasional. Dengan kata lain,penataan ruang harus mempertimbangkan dampak perubahan iklim. 
Perubahan iklim berpengaruh besar terhadap kegiatan budidaya pertanian dan lingkungan yang lebih luas. Artinya, perubahan iklim mempunyai keterkaitan yang cukup erat dengan pola pemanfaatan ruang dan aspek-aspek kewenangan didalamnya, seperti kawasan permukiman, kawasan budidaya pertanian, sistem jaringan prasarana dan lain sebagainya. Selain itu dampak dari penyimpangan iklim adalah terjadinya bencana seperti bencana tanah longsor dan banjir yang disebabkan oleh curah hujan yang tinggi. Hal ini berpengaruh terhadap penataan ruang khususnya aspek alokasi pemanfaatan ruang. Sehingga dalam mengalokasikan pemanfaatan ruang harus memperhatikan daerah rawan bencana.

Adaptasi pola ruang merupakan suatu upaya rencana pola ruang untuk menyesuaikan dengan terjadinya peningkatan suhu udara dan curah hujan. Dengan memaksimalkan penyerapan $\mathrm{CO}_{2}$, pelepasan $\mathrm{O}_{2}$, penyerapan air ke dalam tanah, antisipasi terjadinya masalah kesehatan dan bencana yang disebabkan oleh perubahan iklim. Berikut merupakan upaya yang dapat dilakukan untuk beradaptasi terhadap perubahan iklim ditinjau dari dampak yang ditimbulkan.

\section{Ruang Terbuka Hijau (RTH)}

Berdasarkan Peraturan Menteri Pekerjaan Umum Nomor 05 tahun 2008 tentang Pedoman Penyediaan dan Pemanfaatan Ruang Terbuka Hijau di Kawasan Perkotaan, fungsi utama RTH adalah sebagai paru-paru kota, sebagai peneduh, produsen oksigen, penyerap air hujan, penyedia habitat satwa, penyerap polutan media udara, air, dan tanah, penahan angin, serta pengatur iklim mikro agar system sirkulasi udara dan air secara alami dapat berlangsung lancar. Ruang terbuka hijau dapat mengurangi emisi gas rumah kaca berupa $\mathrm{CO}_{2}$ yang ditimbulkan oleh berbagai aktivitas di kawasan perkotaan dengan menyerap gas tersebut dan mengubahnya menjadi oksigen melalui proses fotosintesis dengan bantuan cahaya matahari sehingga RTH dapat mengurangi temperatur pada wilayah tersebut [7].

\section{Hutan kota}

Penghijauan merupakan solusi cerdas dan inovatif untuk menjawab tantangan permasalahan kota dan perubahan iklim. Penghijauan tersebut ialah penanaman pohon untuk meningkatkan kualitas lingkungan antara lain pada areal fasilitas sosial/umum, ruang terbua hijau, jalur hijau, permukiman, maupun taman. Upaya penghijauan tersebut merupakan salah satu tindak lanjut dari komitmen pemerintah tentang penurunan emisi $26 \%$ pada tahun 2020. Ketentuan luas hutan kota tersebut dapat disesuaikan dengan peraturan yang telah ada sebelumnya yaitu Peraturan Pemerintah Nomor 63 Tahun 2002 [8] tentang Hutan Kota dan Peraturan Menteri Kehutanan Nomor 71 Tahun 2009 [9] yaitu minimal penyediaan hutan kota 10\% dari wilayah perkotaan. Maksud dari ketentuan tersebut ialah untuk menekan atau mengurangi peningkatan suhu udara di perkotan, mencegah terjadinya penurunan air tanah dan permukaan tanah, serta mencegah terjadinya banjir atau genangan maupun kekeringan.

\section{Pertanian}

Pola hujan yang tidak menentu dan perubahan suhu akan mengurangi produktivitas pertanian. Menurut Kementerian Lingkungan Hidup [10], naiknya curah hujan akan mempercepat erosi tanah sehingga akan mengurangi hasil panen dari tanaman dataran tinggi. Selain itu musim kemarau panjang dan banjir juga menjadi penyebab utama terjadinya gagal panen. Perubahan iklim akan mempengaruhi hasil panen yang kemungkinan 
besar akan berkurang disebabkan oleh semakin keringnya lahan akibat musim kemarau yang lebih panjang. Oleh karena itu perlu upaya untuk menghadapi masalah tersebut. Berdasarkan Pedoman Umum Adaptasi Perubahan Iklim Sektor Pertanian oleh Badan Penelitian dan Pengembangan Pertanian Kementerian Pertanian [11], adaptasi pola ruang sektor pertanian terhadap perubahan iklim ialah dengan tetap mempertahankan dan memperluas areal pertanian yaitu dengan melaksanakan secara tegas sanksi/aturan yang berkaitan dengan konversi lahan pertanian, dan menyusun database wilayah yang rawan terkonversi dan menetapkan prioritas wilayah pengembangan pertanian pangan baru dan program dengan pentahapan yang jelas.

\section{KESIMPULAN}

1. Dampak perubahan iklim di Kalimantan Tengah menyebabkan tingkat kasus penyakit Demam berdarah meningkat dari tahun $2016-$ 2017 karena merupakan kemarau basah yang menyebabkan perkembangbiakan jentik nyamuk lebih cepat berkembang biak dan Malaria meningkat dan kasus penyakit malaria terlihat tinggi di tahun 2011 di karenakan tahun tersebut merupakan kemarau ekstrim dengan fenomena el nino.

2. Adaptasi terhadap Perubahan Iklim di Kalimantan Tengah adalah dilakukannya Ruang Terbuka Hijau, Hutan kota, dan Sistem Pertanian yang ramah iklim.

\section{REFERENSI}

[1] IPCC. 2007. Impacts, Adaptation and Vulnerability. Contribution of Working Group II to the Fourth Assessment Report of the Intergovernmental Panel on Climate Change.

[2] Peraturan Gubernur Kalimantan Tengah Nomor 36 Tahun 2012 tentang Rencana Aksi Daerah
Penurunan Emisi Gas Rumah Kaca Kalimantan Tengah. Palangka Raya: Gubernur Kalimantan Tengah.

[3] Dinas kehutanan Propinsi Kalimantan Tengah, 2019. Status Kawasan Hutan Kalimantan Tengah. Palangka Raya.

[4] Badan Meteorologi Klimatologi dan Geofisika Kota Palangka Raya, 2018. Buletin Iklim. Analisis Hujan Maret 2018. Prakiraan Hujan Mei-Juni-Juli 2018, Informasi Kekeringan Januari - Maret 2018, Prakiraan Kekeringan Bulan Mei - Juli 2018. Stasiun BMKG Kota Palangka Raya. Palangka Raya.

[5] Dinas Kesehatan Provinsi Kalimantan Tengah, 2017. Profil Kesehatan Provinsi Kalimantan Tengah. Palangka Raya.

[6] Stern, N. 2006. Stern Review: The Economics of Climate Change. London : HM Treasuty.

[7] Khairunnisa, Ezra S. 2010. Evaluasi Fungsi ekologis Ruang Terbuka Hijau di Kota Bandung Dalam Upaya Pengendalian Iklim Mikro Berupa pemanasan Lokal dan Penyerapan Air. Jurnal Perencanaan Wilayah A Volume 2 Nomor 2.

[8] Pemerintah Indonesia. 2002. Peraturan Pemerintah Nomor 63 Tahun 2002 tentang hutan kota. Jakarta: Pemerintah Indonesia.

[9] Kementerian Kehutanan. 2009. Peraturan Menteri Kehutanan Nomor 71 Tahun 2009 tentang Pedoman Penyelenggaraan Hutan Kota. Jakarta: Kementerian Kehutanan.

[10] Kementerian Lingkungan Hidup. 2012. Kajian Risiko dan Adaptasi Perubahan iklim Malang Raya. Jakarta: kemetrian Lingkungan Hidup

[11] Badan Penelitian dan pengembangang Pertanian Kementerian Pertanian. 2011. Pedoman Umum Adaptasi Perubahan Iklim Sektor Pertanian.Jakarta: Kementerian Pertanian. 